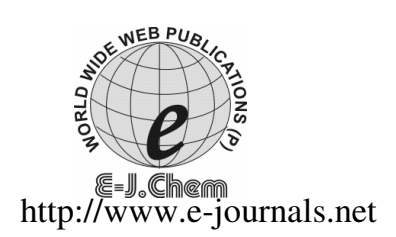

\title{
Synthesis, Crystal Structural Characterization and Biological Properties of Thiosemicarbazones of Schiff Bases Derived from 4-Acyl-2-pyrazoline-5-one
}

\author{
ARJUNSINH RANA*, NAYAN PAREKH ${ }^{\S}$, \\ HARISH DABHI ${ }^{\S}$, DIPAK BHOI ${ }^{\#}$ and NIRAJ KUMARI \\ *Department of Chemistry \\ Navajivan Science College, Dahod-389151, Gujarat, India \\ ${ }^{\S}$ Torrent Research Centre \\ Village Bhat, Ahmedabad-382428, Gujarat, India \\ "Department of Chemistry \\ J \& J Science College, Nadiad-387001, Gujarat India \\ Banaras Hindu University (BHU), Varanasi -221005, India \\ dr.arjunshinrana@yahoo.co.in
}

Received 26 July 2010; Accepted 15 October 2010

\begin{abstract}
A novel synthesis, single crystal and biological activity of 4-acylthiosemicarbazone-3-methyl-1-(4`-methylphenyl)-2-pyrazolin-5-one by condensation of 4-acyl-3-methyl-1-(4-methylphenyl)-2-pyrazolin-5-one with thiosemicarbazide was carried out. The compounds were characterized on the basis of elemental analysis, IR, ${ }^{1} \mathrm{H}$ NMR, Mass, DSC and ${ }^{13} \mathrm{C}$ NMR spectral data. The compounds were tested for their antibacterial activity against various gram $+v e$ and -ve bacteria. The results were compared with the marketed drugs. The crystal structure was determined by single x-ray diffraction. 4-Acetyl thiosemicarbazone3-methyl-1-(4-methylphenyl)-2-pyrazolin-5-one(AcPTMP-ths) crystallizes in the monoclinic system, space group $P 21 / n$ with $a=6.0828(7) \AA, b=29.547(4) \AA$, $c=7.9101(15) \AA, \alpha=90^{\circ}, \beta=95.602(15)^{\circ}, \gamma=90^{\circ}, V=1414.9(4) \AA^{3}, Z=4, D_{c}=1.429$ $\mathrm{mg} / \mathrm{m}^{3}$ and 4-Propionylthiosemicarbazone-3-methyl-1-(4-methylphenyl)-2pyrazolin-5-one (PropPTMP-ths) crystallizes in the monoclinic system, space group $\mathrm{P} 21 / \mathrm{c}$ with $\mathrm{a}=13.5622(10) \AA \mathrm{A}, \mathrm{b}=13.3671(12) \AA \mathrm{A}, \mathrm{c}=22.151(2) \AA, \alpha=90^{\circ}$, $\beta=93.13(7)^{\circ}, \gamma=90^{\circ}, V=4010.1(6) \AA^{3}, Z=8, D_{c}=1.310 \mathrm{mg} / \mathrm{m}^{3}$. The compounds were screened for antibacterial properties and exhibited potential activity.
\end{abstract}

Keywords: 4-Acyl-2-pyrazoline-5-one, Thiosemicarbazone, Biological activity, Single crystal.

\section{Introduction}

The chemistry of thiosemicarbazones has received considerable attention in view of their variable bonding modes, promising biological implications and structural properties ${ }^{1-3}$. 
The structure diversity of thiosemicarbazide based compounds is considerably increased not only due to the condensation of the different carbonyls but also due to the alkylation of the different part of the thiosemicarbazide ${ }^{4}$. Thiosemicarbazone usually act as chelating ligands with transition metal ion, bonding through the sulphur and hydrazine nitrogen atom. Thiosemicarbazones and their complexes have received considerable attention because of their pharmacological activities ${ }^{5}$. The pyrazolone derivatives have attracted much attention because of their interesting structural properties and application ${ }^{6-11}$.

Thiosemicarbazones can coordinate to metal as neutral molecules or after deprotonation, as anionic ligands and can adopt variety different coordination modes. The possibility of their being able to transmit electronic effects between a reduce unit and metal centre is suggested by the delocalization of the $\pi$ bonds in the thiosemicarbazone chain ${ }^{12}$. Thiosemicarbazone compounds can be converted in to complexes by reaction with metal ions and the reaction product has very important uses ${ }^{13,6}$.

There are different substituted amide bonds (-CONH-) in structure of these compounds, therefore most of them have good biological activities and there are some reports about their use as herbicides and bactericides ${ }^{14,24}$. In order to exploit new type of chetale extracting and biological active compound, two type of 4-acyl-3-methyl-1-(4-methylphenyl)-2-pyrazolin5 -one are used in present study to react with thiosemicarbazide and new compound of 4-acylthiosemicarbazone-3-methyl-1-(4`-methylphenyl)-2-pyrazolin-5-one are synthesized and crystallization. Literature survey revels that few 4-acylthisemicarbazones are reported ${ }^{11-16}$. But single crystal and biological studies of 4-acetyl thiosemicarbazone-3-methyl-1-(4methylphenyl)-2-pyrazolin-5-one (AcPTMP-ths), 4-Propionylthiosemicarbazone-3-methyl-1(4`-methylphenyl)-2-pyrazolin-5-one (PropPTMP-ths), which have never been reported.

The present study reports synthesis and single crystal study of AcPTMP-ths and PropPTMP-ths in continuation of our earlier work. Several 4-acyl-3-methyl-1-phenyl-2pyrazolin-5-ones were prepared and applied for the separation of the metals ${ }^{14-20,21}$. Preparation of amine substituted of thiosemicarbazones of 4-acyl-3-methyl-(4-methylphenyl) -2-pyrazolin-5-ones and their metal complexes work is in progress.

The new compound of pyrazolone thiosemicarbazone (Figure 1) reported in our earlier paper was synthesized ${ }^{13}$. As an extension of this work, we herein report the synthesis, structural characterization and antibacterial activity of compound AcPTMP-ths and PropPTMP-ths.

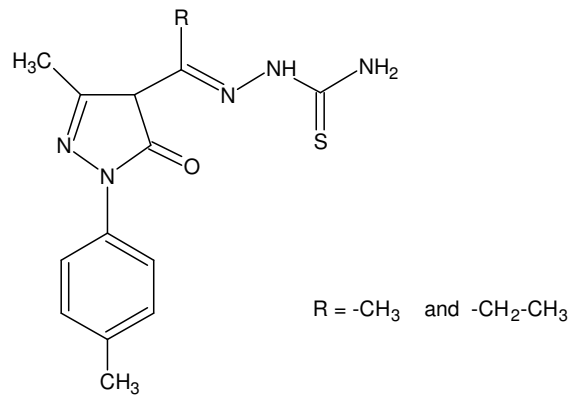

Figure 1. Pyrazolone thiosemicarbazone

Many 4-acyl derivatives of 1-phenyl-3-methyl-2-pyrazoline-5-one have been prepared and applied for the metal complexes. The reaction pyrazolone with acetyl chloride and propionyl chloride were carried out under the ordinary condition mentioned below. 
Reaction formulas are as follow in Scheme 1 and the reaction 4-acyl-2-pyrazoline-5-one with thiosemicarbazide produce Schiff base $\mathrm{e}^{11,21-23}$ was carried out in alcohol such as ethanol or methanol at reflux temperature and crystallization by aqueous alcohol for purification as shown Scheme 2. Reaction formulas are as follow in scheme 2 A yellow prismatic crystals of the titled compounds obtained.<smiles>CCCCCCC(=O)Nc1ccc(C)cc1</smiles><smiles>CCC(=O)C1C(=O)N(c2ccc(C)cc2)N=C1C</smiles>

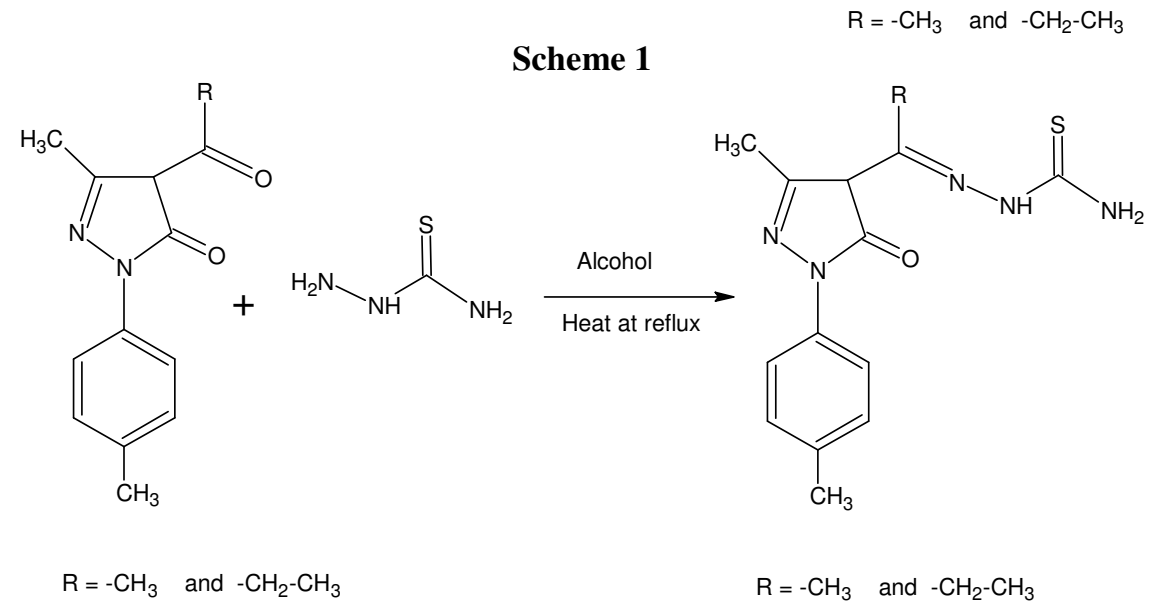

\section{Scheme 2}

\section{Experimental}

Reagent grade and pure (HPLC) grade solvents and chemicals were used during the experiments. 1-(Phenyl-4-methyl)-3-methyl-2-pyrazoline-5-one (PTMP) was provided from Prima chemicals (Ahmedabad, India) as free sample. Acetyl chloride, propionyl chloride, calcium hydroxide, acetic acid, 4-methylphenyl hydrazine, methanol, strong hydrochloric acid, thiosemicarbazide dioxane was purchased from s.d.fine chemicals (India). The microorganism strains for antibacterial activity were purchased from Pathoteq Biological Laboratories (India)). Nutrient media (Agar) was purchased from Hi-media

\section{Measurments}

The FT-IR spectra were recorded on a Perkin-Elmer infrared spectrophotometer Model 2000 in the range of $4000-400 \mathrm{~cm}^{-1}$ by using $\mathrm{KBr}$ pellets (Vaibhav Analytical, Ahmedabad, India). Elemental analysis (C, H, N and S) was performed on a Perkin-Elmer Model-2400 elemental analyzer (SCICAR, vallabhvidhyanagar, Gujarat (India)). Nuclear magnetic resonance spectra $\left({ }^{1} \mathrm{H}\right.$ NMR and $\left.{ }^{13} \mathrm{C}-\mathrm{NMR}\right)$ were recorded on a Bruker $-400 \mathrm{MHz}$, spectrometer using 
DMSO-d6 as a solvent (CSMCRI Bhavnagar, India). Single crystal x-ray powder diffraction analysis done at IIT, Powai, Mumbai.

\section{Preparation of 4-acyl-2-pyrazoline-5-one}

Preparation of 3-methyl-1-(4-methylphenyl)-4-propyl-2-pyrazoline-5-one (PropPTMP)

1,4-Dioxane solution (250 mL) of 3-methyl-1-(4`-methylphenyl)-2-pyrazoline-5-one (PTMP) $(25.0 \mathrm{~g})$ and propionyl chloride $(13.25 \mathrm{~mL})$ was refluxed for $2 \mathrm{~h}$ with calcium hydroxide $(13.97 \mathrm{~g})$ and cooled to room temperature. Dilute hydrochloric acid $(45 \mathrm{~mL}$ conc. $\mathrm{HCl}$ in $200 \mathrm{~mL}$ water), added slowly to the reaction mass at below $25^{\circ} \mathrm{C}$. Solid light yellow to brown product was filtered and washed with water. 3-Methyl-1-(4methylphenyl)-4-propyl-2-pyrazoline-5-on (PTMPP) is light yellow powder and its yield is $89 \%$, m.p: $101.19^{\circ} \mathrm{C}$.

${ }^{1} \mathrm{H}$ NMR(400MHz, $\delta \mathrm{ppm}$, in DMSO-d $\left.\mathrm{d}_{6}\right) 1.031-2.33\left(\mathrm{t}, 5 \mathrm{H}, \mathrm{CH}_{2} \mathrm{CH}_{3}\right), 2.41(\mathrm{~S}, 3 \mathrm{H}$, PZ-CH $\left.{ }_{3}\right), 2.81\left(\mathrm{~S}, 2 \mathrm{H}, \mathrm{NH}_{2}\right), 7.2 \sim 7.5(\mathrm{~m}, 5 \mathrm{H}, \mathrm{Ph})$. FTIR (KBr pellets, $v$ in $\left.\mathrm{cm}^{-1}\right) 3432(\mathrm{w})$ $(\mathrm{N}-\mathrm{H}), 3292(\mathrm{w})(\mathrm{O}-\mathrm{H}), 1621(\mathrm{~s})(\mathrm{Pz}-\mathrm{C}=\mathrm{O}), 1553(\mathrm{~s}), 1512(\mathrm{~s}), 1441(\mathrm{~s}) \mathrm{Ph}, 1404(\mathrm{~m}), 1364(\mathrm{~m})$ (Pz). Mass $245 \mathrm{M}^{+}$. Elemental anal. $\mathrm{C}_{14} \mathrm{H}_{16} \mathrm{~N}_{2} \mathrm{O}_{2}$; mol.wt: 244.29: calcd. $\mathrm{C}(68.83 \%)$, $\mathrm{H}(6.60 \%), \mathrm{N}(11.47 \%)$ and found $\mathrm{C}(68.71 \%), \mathrm{H}(6.656 \%), \mathrm{N}(11.48 \%)$. 3-Methyl-1(4-methylphenyl)-4-acetyl-2-pyrazoline-5-one(AcPTMP) is light yellow powder and its yield is $82 \%$,m.p: $103.14^{\circ} \mathrm{C}$.

${ }^{1} \mathrm{H}$ NMR(400MHz, $\delta \mathrm{ppm}$, in DMSO-d $\left.\mathrm{d}_{6}\right) 2.33\left(\mathrm{~s}, 3 \mathrm{H}, \mathrm{CH}_{3}\right), 2.40\left(\mathrm{~S}, 3 \mathrm{H}, \mathrm{PZ}_{-} \mathrm{CH}_{3}\right)$, 2.39(S, 2H, NH $), 7.2 \sim 7.5(\mathrm{~m}, 5 \mathrm{H}, \mathrm{Ph})$. FTIR (KBr pellets, $v$ in $\left.\mathrm{cm}^{-1}\right) 2924(\mathrm{w})(\mathrm{N}-\mathrm{H})$, 2967(w)(O-H), 1635(s)(Pz-C=O), 1552(s), 1510(s), 1441(s)Ph, 1364(m)1369(m)(Pz). Mass 230.8. Elemenatl anal. $\mathrm{C}_{13} \mathrm{H}_{14} \mathrm{~N}_{2} \mathrm{O}_{2}$ mol.wt: 230.26: calcd. $\mathrm{C}(67.81 \%), \mathrm{H}(6.13 \%)$, $\mathrm{N}(12.17 \%)$ and found $\mathrm{C}(67.67 \%), \mathrm{H}(6.151 \%)$ and $\mathrm{N}(12.15 \%)$.

\section{Preparation of 4-acylthiosemicarbazon-2-pyrazoline-5-one}

Preparation of 4-propionylthiosemicarbazone-3-methyl-1-(4-methylphenyl)-2pyrazolin-5-one (PropPTMP-ths)

Ethanol or methanol solution $(250 \mathrm{~mL})$ of 3-methyl-1-(4-methylphenyl)-4-propionyl-2pyrazoline-5-one (PropPTMP) (25.0 g, $1 \mathrm{~mol}$ ) and thiosemicarbazide or $\mathrm{N}$-4-methylthiosemicarbazide or 4,4-dimethyl thiosemicarbazide or 4,4-diphenyl thiosemicarbazide $(1.1 \mathrm{~mol})$ was taken and to this reaction mass catalytic amount of acetic acid $(\sim 15-20 \mathrm{~mL})$ was added and refluxed for 3 to $5 \mathrm{~h}$. Cooled to room temperature. Solid light yellow to brown product was filtered and washed with methanol or ethanol. 4-Propionylthiosemicarbazone-3-methyl-1-(4`-methylphenyl)-2-pyrazolin-5-one PropPTMP-ths) was light yellow powder and its yield was $80 \%$. Crystals of the compound was obtained by slow diffusion from DMF/ methanol solution and was stable in the air for long time. Attempt to grow crystals of the compound in many different solvents was unsuccessful.

${ }^{1} \mathrm{H}$ NMR(400MHz, $\delta \mathrm{ppm}$, in DMSO-d $\left.\mathrm{D}_{6}\right): 1.31-2.2\left(\mathrm{~m}, 5 \mathrm{H}, \mathrm{CH}_{2} \mathrm{CH}_{3}\right), 2.33(\mathrm{~S}, 3 \mathrm{H}$, PZ-CH $\left.{ }_{3}\right), 2.80\left(\mathrm{~S}, 2 \mathrm{H}, \mathrm{NH}_{2}\right), 7.2 \sim 7.8(\mathrm{~m}, 5 \mathrm{H}, \mathrm{Ph}), 10.07(\mathrm{~S}, 1 \mathrm{H}, \mathrm{NH}-\mathrm{tsc}), 12.10(\mathrm{~S}, 1 \mathrm{H}$, $\mathrm{Pz}-\mathrm{NH}) .{ }^{13} \mathrm{C}$ NMR(400MHz, $\delta \mathrm{ppm}$, in $\left.\mathrm{DMSO}-\mathrm{d}_{6}\right) 164.66(\mathrm{C}=\mathrm{S}) \quad 146.52(\mathrm{Pz}-\mathrm{C}=\mathrm{O})$ 129.03-118.54(Ph) 117.94-136.42(C-N) $18.45\left(\mathrm{pz}^{\left.-\mathrm{CH}_{3}\right)} 14.08\left(\mathrm{C}-\mathrm{CH}_{3}\right) 38.76-40.01(\mathrm{Ph}-\right.$ $\mathrm{CH}_{3}$ ). FTIR (KBr pellets, $v$ in $\left.\mathrm{cm}^{-1}\right) 3426(\mathrm{w})(\mathrm{N}-\mathrm{H}), 3111 . .2867(\mathrm{br}, \mathrm{m}), 1627(\mathrm{~s})(\mathrm{Pz}-\mathrm{C}=\mathrm{O})$, 1540(s), 1510(s), 1459(s)(Ph), 1387(m)(Pz), 1364(s), 1243(s), 822(m) (C=S). MASS: 316 $\mathrm{M}^{-}$Elem. Anal. (\%), $\mathrm{C}_{15} \mathrm{H}_{19} \mathrm{~N} 5 \mathrm{OS}(317.4)$ : Calc. (\%) $\mathrm{C}(56.76 \%) \mathrm{H}(6.03 \%) \mathrm{N}(22.06 \%)$ $\mathrm{S}(10.10 \%)$. found (\%) C(56.13\%) H(6.04\%) N(22.65\%) S(11.24\%). M.p.: $178.88^{\circ} \mathrm{C}$. 
4-Acetylthiosemicarbazone-3-methyl-1-(4`-methylphenyl)-2-pyrazolin-5-one (AcPTMP-ths), was light yellow powder and its yield was $90 \%$. Crystals of the compound was obtained by slow diffusion from DMSO/ Methanol solution and was stable in the air for long time. Attempt to grow crystals of the compound in many different solvents was unsuccessful.

${ }^{1} \mathrm{H}$ NMR(400MHz, $\delta$ ppm, in DMSO-d $\left.\mathrm{d}_{6}\right): 2.29\left(\mathrm{~s}, 3 \mathrm{H}, \mathrm{CH}_{3}\right), 2.5\left(\mathrm{~S}, 3 \mathrm{H}, \mathrm{PZ}-\mathrm{CH}_{3}\right), 2.6(\mathrm{~S}, 2 \mathrm{H}$, $\left.\mathrm{NH}_{2}\right), 7.18 \sim 7.85(\mathrm{~m}, 5 \mathrm{H}, \mathrm{Ph}), 10.03(\mathrm{~S}, 1 \mathrm{H}, \mathrm{NH}-\mathrm{tsc}), 12.10(\mathrm{~S}, 1 \mathrm{H}, \mathrm{Pz}-\mathrm{NH}) .{ }^{13} \mathrm{C}$ NMR $\left(400 \mathrm{MHz}, \delta \mathrm{ppm}\right.$, in DMSO-d $\left.{ }_{6}\right) 164.82(\mathrm{C}=\mathrm{S}) 147.73(\mathrm{Pz}-\mathrm{C}=\mathrm{O}) 129.61-118(\mathrm{Ph}) 118.51-137.05$ (C-N) 17.31(pz- $\left.\mathrm{CH}_{3}\right)$ 14.82(C- $\left.\mathrm{CH}_{3}\right) 39.32-40.57\left(\mathrm{Ph}-\mathrm{CH}_{3}\right)$. FTIR ( $\mathrm{KBr}$ pellets, $v$ in $\mathrm{cm}^{-1}$ ) 3747(w)(N-H), 3214..2865(br, m), 1624(s)(Pz-C=O),1540(s), 1511(s), 1472(s)Ph, 1364(m) $(\mathrm{Pz}), 1324(\mathrm{~s}), 1208(\mathrm{~s}), 827(\mathrm{~m})(\mathrm{C}=\mathrm{S})$. MASS: $304 \mathrm{M}^{+}$. Elem. Anal. (\%), $\mathrm{C}_{14} \mathrm{H}_{17} \mathrm{~N} 5 \mathrm{OS}$ (303.38): Calc. (\%) C (55.42\%) H(5.65\%) N(23.08\%) S(10.57\%). found C (55.4\%) $\mathrm{H}(5.63 \%)$ $\mathrm{N}(23.04 \%) \mathrm{S}(10.98 \%)$. DSC: $205.28^{\circ} \mathrm{C}$.

Above all ligands are in crystalline form as per X-RPD pattern done on X'pert PRO Panalytical using Cu, Generator setting-45 kV / 40 m A; Goniometer (Pw3050/60( $\theta / \theta)$, $240 \mathrm{~mm}$ Gonoimeter radius.

\section{Results and Discussion}

The new Schiff base 4-acyl thiosemicarbazone-3-methyl-1-(4-methylphenyl)-2-pyrazolin5-one would be good precursors for metal complexes like lanthanide series and others metals like $\mathrm{Co}, \mathrm{Cr}, \mathrm{Mn}, \mathrm{Mg}, \mathrm{Pd}, \mathrm{Ni}, \mathrm{Fe}, \mathrm{Zn}, \mathrm{Ca}, \mathrm{Hg}$ and $\mathrm{As}$ in bidentet or tridentate respectively. We disclosed analytical data like elemental analysis, ${ }^{1} \mathrm{H}$ NMR, ${ }^{13} \mathrm{C}$ NMR, IR, Mass spectra, DSC and x-ray powder diffraction for new Schiff base ligands formation confirmation. The single crystal preparation and biological activity of metal complexes synthesized from above ligands is in progress.

\section{Structural determination}

Chemical shift of hydrogen in the IR spectrum, the $v(\mathrm{~N}-\mathrm{H})$ spectral region is broad, showing the existence of N-H-O hydrogen bond. The band for $v(C=O)$ at $1628 \mathrm{~cm}^{-1}$ is at lower wave number than that usually found for carbonyls, reflecting the involvement in hydrogen bonding with $\mathrm{NH}$ of the thiosemicarbazone and pyrazol-5-one compound. In ${ }^{1} \mathrm{H}$ NMR $\mathrm{N}(1)$ is easily distinguished from that of $\mathrm{N}(2)$ because the latter $(7.161 \mathrm{ppm})$ appears as a doublet due to that the two hydrogen atom on $\mathrm{N}(2)$ are nonequivalent because one of them is involved in hydrogen bonding, which is consistent with the crystal structure analysis. The single peak at $8.3 \mathrm{ppm}$ is assignable to the $\mathrm{N}(1)-\mathrm{H}$. The single of $10.2 \mathrm{ppm}$ is not a unit because $\mathrm{N}(5)$ share the same hydrogen with $\mathrm{O}$ on the neighboring molecule.

Suitable x-ray quality crystals of the compounds AcPTMP-ths \& PropPTMP-ths were grown from dimethylsulfoxide(DMSO) and methanol solvent mixture at room temperature, and $\mathrm{x}$-ray crystallographic data are recorded by mounting a single-crystal of compound PropPTMP-ths $(0.23 \times 0.21 \times 0.18) \mathrm{mm}^{3}$ and compound AcPTMP-ths $(0.26 \times 0.19 \times 0.15) \mathrm{mm}^{3}$ on glass fibers. Oxford diffraction XCALIBUR-S CCD area detector diffractometer equipped with an LN-2 low-temperature attachment was used for the cell determination and intensity data collection. Appropriate empirical absorption corrections were applied using multi-scan programs. Monochromated Mo K $\alpha$ radiation $(\lambda=0.71073 \AA)$ was used for the measurements. The crystal structures were solved by direct methods and refined by full matrix least squares SHELXL-97. Crystallographic data are presented in Table 1 where as bond length and bond angles are summarized in Table 2. A computational program PLATON $^{24}$ was used to study the involvement of weak interactions and corresponding distances are summarized in Table 3. 
Table 1. Summary of crystallographic data for compounds PropPTMP-ths \& AcPTMP-ths

\begin{tabular}{|c|c|c|}
\hline Parameters & PropPTMP-ths & AcPTMP-ths \\
\hline Formula & $\mathrm{C}_{34} \mathrm{H}_{50} \mathrm{~N}_{10} \mathrm{O}_{4} \mathrm{~S}_{4}$ & $\mathrm{C}_{14} \mathrm{H}_{18} \mathrm{~N}_{5} \mathrm{OS}$ \\
\hline M & 791.08 & 304.39 \\
\hline Crystal system & Monoclinic, P 21/c & Monoclinic \\
\hline Temperature & $150(2) \mathrm{K}$ & $150(2) \mathrm{K}$ \\
\hline Space group & $\mathrm{P} 2{ }_{1} / \mathrm{c}$ & $\mathrm{P} 21 / \mathrm{n}$ \\
\hline$a / \AA$ & $13.5622(10)$ & $6.0828(7)$ \\
\hline$b / \AA$ & $13.3671(12)$ & $29.547(4)$ \\
\hline$c / \AA$ & $22.151(2)$ & $7.9101(15)$ \\
\hline$\alpha\left(^{\circ}\right)$ & 90 & 90 \\
\hline$\beta\left(^{\circ}\right)$ & $93.013(7)$ & $95.602(15)$ \\
\hline$\gamma\left({ }^{\circ}\right)$ & 90 & 90 \\
\hline$V / \AA^{3}$ & $4010.1(6)$ & $1414.9(4)$ \\
\hline$Z$ & 8 & 4 \\
\hline$D_{c} / \mathrm{mg} \cdot \mathrm{m}^{-3}$ & 1.310 & 1.429 \\
\hline Reflns. collected & 28743 & 8708 \\
\hline Reflns. unique & 7054 & 2494 \\
\hline $\mathrm{R}(i n t)$ & 0.1555 & 0.1002 \\
\hline \multirow[t]{3}{*}{ Index ranges } & $-16<=\mathrm{h}<=16$ & $-7<=\mathrm{h}<=7$ \\
\hline & $-15<=\mathrm{k}<=14$ & $-35<=\mathrm{k}<=35$ \\
\hline & $-26<=1<=26$ & $-9<=1<=9$ \\
\hline Refinement method & Full-matrix, least squares on $F^{2}$ & \\
\hline$w R_{2}$ & 0.2059 & 0.1531 \\
\hline$R_{l}$ & 0.0846 & 0.0706 \\
\hline GoF & 1.103 & 0.900 \\
\hline
\end{tabular}

Table 2. Selected bond lengths and bond distances for complexes PropPTMP-ths \& AcPTMP-ths

\begin{tabular}{cccccc}
\hline \multicolumn{5}{c}{ PropPTMP-ths } \\
\hline $\mathrm{S}(1)-\mathrm{C}(1)$ & $1.682(6)$ & $\mathrm{C}(1)-\mathrm{N}(1)-\mathrm{H}(1 \mathrm{~N})$ & $115(4)$ & $\mathrm{O}(1)-\mathrm{C}(6)-\mathrm{N}(4)$ & $126.2(5)$ \\
$\mathrm{O}(1)-\mathrm{C}(6)$ & $1.246(6)$ & $\mathrm{C}(1)-\mathrm{N}(2)-\mathrm{N}(3)$ & $121.3(4)$ & $\mathrm{O}(1)-\mathrm{C}(6)-\mathrm{C}(5)$ & $129.1(5)$ \\
$\mathrm{N}(1)-\mathrm{C}(1)$ & $1.332(7)$ & $\mathrm{N}(3)-\mathrm{N}(2)-\mathrm{H}(2)$ & 119.3 & $\mathrm{~N}(4)-\mathrm{C}(6)-\mathrm{C}(5)$ & $104.8(4)$ \\
$\mathrm{N}(1)-\mathrm{H}(1 \mathrm{~N})$ & $0.93(6)$ & $\mathrm{C}(6)-\mathrm{N}(4)-\mathrm{N}(5))$ & $111.9(4)$ & $\mathrm{N}(6)-\mathrm{C}(16)-\mathrm{N}(7)$ & $117.8(5)$ \\
$\mathrm{N}(2)-\mathrm{C}(1)$ & $1.348(7)$ & $\mathrm{C}(6)-\mathrm{N}(4)-\mathrm{C}(9)$ & $128.0(4)$ & $\mathrm{N}(6)-\mathrm{C}(16)-\mathrm{S}(2)$ & $123.7(5)$ \\
$\mathrm{N}(2)-\mathrm{N}(3)$ & $1.394(6)$ & $\mathrm{C}(16)-\mathrm{N}(6)-\mathrm{H}(2 \mathrm{~N})$ & $126(4)$ & $\mathrm{N}(8)-\mathrm{C}(17)-\mathrm{C}(18)$ & $119.2(5)$ \\
$\mathrm{S}(222)-\mathrm{O}(222)$ & $1.484(4)$ & $\mathrm{C}(17)-\mathrm{N}(8)-\mathrm{N}(7)$ & $121.3(4)$ & $\mathrm{O}(2)-\mathrm{C}(21)-\mathrm{N}(9)$ & $125.8(4)$ \\
$\mathrm{S}(222)-\mathrm{C}(333)$ & $1.775(7)$ & $\mathrm{C}(21)-\mathrm{N}(9)-\mathrm{C}(24)$ & $128.2(4)$ & $\mathrm{N}(9)-\mathrm{C}(21)-\mathrm{C}(20)$ & $104.9(4)$ \\
$\mathrm{N}(4)-\mathrm{N}(5)$ & $1.4116)$ & $\mathrm{N}(1)-\mathrm{C}(1)-\mathrm{S}(1)$ & $123.7(5)$ & $\mathrm{O}(111)-\mathrm{S}(111)-\mathrm{C}(111)$ & $106.0(3)$ \\
$\mathrm{N}(4)-\mathrm{C}(9)$ & $1.422(6)$ & $\mathrm{N}(2)-\mathrm{C}(1)-\mathrm{S}(1)$ & $119.0(4)$ & $\mathrm{O}(111)-\mathrm{S}(111)-\mathrm{C}(222)$ & $104.8(3)$ \\
$\mathrm{C}(12)-\mathrm{C}(14)$ & $1.383(7)$ & $\mathrm{N}(3)-\mathrm{C}(2)-\mathrm{C}(5)$ & $116.7(4)$ & $\mathrm{C}(111)-\mathrm{S}(111)-\mathrm{C}(222)$ & $97.9(3)$ \\
$\mathrm{N}(7)-\mathrm{N}(8)$ & $1.404(6)$ & $\mathrm{C}(5)-\mathrm{C}(2)-\mathrm{C}(3)$ & $124.8(5)$ & $\mathrm{O}(222)-\mathrm{S}(222)-\mathrm{C}(333)$ & $103.9(3)$ \\
& & $\mathrm{AcPTMP}-\mathrm{ths}$ & & \\
$\mathrm{S}(1)-\mathrm{C}(1)$ & $1.672(5)$ & $\mathrm{C}(1)-\mathrm{N}(1)-\mathrm{H}(1 \mathrm{~N})$ & $115(4)$ & $\mathrm{N}(5)-\mathrm{N}(4)-\mathrm{C}(8))$ & $118.2(3)$ \\
$\mathrm{O}(1)-\mathrm{C}(5)$ & $1.249(5)$ & $\mathrm{H}(1 \mathrm{~N})-\mathrm{N}(1)-\mathrm{H}(1 \mathrm{~N})$ & $122(5)$ & $\mathrm{N}(1)-\mathrm{C}(1)-\mathrm{S}(1)$ & $123.7(4)$ \\
$\mathrm{N}(1)-\mathrm{C}(1)$ & $1.331(6)$ & $\mathrm{C}(1)-\mathrm{N}(2)-\mathrm{N}(3)$ & $122.4(4)$ & $\mathrm{N}(2)-\mathrm{C}(1)-\mathrm{S}(1)$ & $119.4(3)$ \\
$\mathrm{N}(2)-\mathrm{N}(3)$ & $1.387(5)$ & $\mathrm{N}(3)-\mathrm{N}(2)-\mathrm{H}(2 \mathrm{~N})$ & $135.7(4)$ & $\mathrm{O}(1)-\mathrm{C}(5)-\mathrm{N}(4)$ & $126.1(4)$ \\
$\mathrm{N}(2)-\mathrm{H}(2 \mathrm{~N})$ & $0.96(5)$ & $\mathrm{C}(2)-\mathrm{N}(3)-\mathrm{N}(2)$ & $120.4(4)$ & $\mathrm{O}(1)-\mathrm{C}(5)-\mathrm{C}(4)$ & $129.0(4)$ \\
$\mathrm{N}(4)-\mathrm{N}(5)$ & $1.396(5)$ & $\mathrm{C}(2)-\mathrm{N}(3)-\mathrm{H}(3 \mathrm{~N})$ & $121(3)$ & $\mathrm{N}(5)-\mathrm{C}(6)-\mathrm{C}(4)$ & $111.5(4)$ \\
$\mathrm{N}(5)-\mathrm{C}(6)$ & $1.305(5)$ & $\mathrm{N}(2)-\mathrm{N}(3)-\mathrm{H}(3 \mathrm{~N})$ & $116(3)$ & $\mathrm{C}(8)-\mathrm{C}(9)-\mathrm{C}(10)$ & $119.4(4)$ \\
$\mathrm{C}(2)-\mathrm{C}(3)$ & $1.494(6)$ & $\mathrm{C}(5)-\mathrm{N}(4)-\mathrm{N}(5)$ & $112.2(3)$ & $\mathrm{C}(8)-\mathrm{C}(9)-\mathrm{H}(9)$ & 120.3 \\
$\mathrm{C}(14)-\mathrm{H}(14)$ & 0.9500 & $\mathrm{C}(5)-\mathrm{N}(4)-\mathrm{C}(8)$ & $129.6(4)$ & $\mathrm{H}(12 \mathrm{~A})-\mathrm{C}(12)-\mathrm{H}(12 \mathrm{~B})$ & 109.5 \\
\hline \multicolumn{7}{c}{} & & &
\end{tabular}


Table 3. Selected parameters for weak interactions in complexes 1 \& 2

\begin{tabular}{|c|c|c|c|c|c|}
\hline $\mathrm{D}-\mathrm{H} \cdots \mathrm{A}$ & $\mathrm{D}-\mathrm{H}(\AA)$ & $\mathrm{H}^{\cdots} \mathrm{A}(\AA)$ & $\mathrm{D} \cdots \mathrm{A}(\AA)$ & $\operatorname{DHA}\left({ }^{\circ}\right)$ & symmetry code \\
\hline \multicolumn{6}{|c|}{ PropPTMP-ths } \\
\hline $\mathrm{N}(1)-\mathrm{H}(1) \mathrm{N}^{\prime} \cdots \mathrm{N}(10)$ & $0.75(7)$ & $2.27(7)$ & $3.020(7)$ & 175(4) & -- \\
\hline $\mathrm{N}(1)-\mathrm{H}(1) \mathrm{N} \cdots \mathrm{S}(2)$ & $0.93(7)$ & $2.48(7)$ & $3.394(6)$ & $169(5)$ & $\mathrm{x},-1+\mathrm{y}, \mathrm{z}$ \\
\hline $\mathrm{N}(2)-\mathrm{H}(2) \cdots \mathrm{O}(111)$ & 0.88 & 2.13 & $2.784(6)$ & 131 & $x, 3 / 2-y,-1 / 2+z$ \\
\hline $\mathrm{N}(6)-\mathrm{H}(2) \mathrm{N} \cdots \mathrm{N}(5)$ & 0.89 & $2.14(7)$ & $2.985(7)$ & $158(6)$ & -- \\
\hline $\mathrm{N}(6)-\mathrm{H}(2) \mathrm{N}^{\prime} \cdots \mathrm{S}(1)$ & 0.89 & $2.13(5)$ & $3.417(5)$ & $175(4)$ & $\mathrm{x}, 1+\mathrm{y}, \mathrm{z}$ \\
\hline $\mathrm{N}(7)-\mathrm{H}(7) \cdots \mathrm{O}(222)$ & 0.88 & 2.06 & $2.762(6)$ & 136 & $1-\mathrm{x}, 2-\mathrm{y}, 1-\mathrm{z}$ \\
\hline $\mathrm{C}(8)-\mathrm{H}(8) \mathrm{C} \cdots \mathrm{O}(2)$ & 0.98 & 2.52 & $3.308(6)$ & 138 & -- \\
\hline $\mathrm{C}(10)-\mathrm{H}(10) \cdots \mathrm{O}(1)$ & 0.95 & 2.44 & $3.308(6)$ & 115 & -- \\
\hline $\mathrm{C}(111)-\mathrm{H}(11 \mathrm{~A}) \cdots \mathrm{O}(111)$ & 0.98 & 2.31 & $2.286(7)$ & 172 & $1-\mathrm{x}, 1-\mathrm{y}, 1-\mathrm{z}$ \\
\hline $\mathrm{C}(111)-\mathrm{H}(11 \mathrm{~B}) \cdots \mathrm{O}(2)$ & 0.98 & 2.45 & $3.136(7)$ & 127 & $\mathrm{x},-1+\mathrm{y}, \mathrm{z}$ \\
\hline $\mathrm{C}(222)-\mathrm{H}(22 \mathrm{C}) \cdots \mathrm{O}(222)$ & 0.98 & 2.50 & $3.220(8)$ & 130 & $1-\mathrm{x}, 1-\mathrm{y}, 1-\mathrm{z}$ \\
\hline $\mathrm{C}(25)-\mathrm{H}(25)^{\cdots} \mathrm{S}(2)$ & 0.95 & 2.41 & $2.943(6)$ & 116 & -- \\
\hline $\mathrm{C}(444)-\mathrm{H}(44 \mathrm{~A}) \cdots \mathrm{S}(2)$ & 0.98 & 2.81 & $3.749(7)$ & 161 & $1-x, 2-y, 1-z$ \\
\hline $\mathrm{C}(444)-\mathrm{H}(44 \mathrm{C}) \cdots \mathrm{O}(111)$ & 0.98 & 2.58 & $3.342(9)$ & 135 & $1-\mathrm{x}, 1-\mathrm{y}, 1-\mathrm{z}$ \\
\hline \multicolumn{6}{|l|}{ AcPTMP-ths } \\
\hline $\mathrm{N}(1)-\mathrm{H}(1) \mathrm{N} \cdots \mathrm{S}(1)$ & $0.79(5)$ & $2.84(5)$ & $3.449(5)$ & $136(5)$ & $-1+\mathrm{x}, \mathrm{y}, \mathrm{z}$ \\
\hline $\mathrm{N}(1)-\mathrm{H}(1) \mathrm{N} \cdots \mathrm{N}(3)$ & $0.79(5)$ & $2.38(5)$ & $2.693(6)$ & $105(5)$ & -- \\
\hline $\mathrm{N}(1)-\mathrm{H}(1) \mathrm{N} \cdots \mathrm{O}(1)$ & $0.79(6)$ & $2.23(6)$ & $2.951(6)$ & $152(5)$ & $1 / 2+x, 1 / 2-y, 1 / 2+z$ \\
\hline $\mathrm{N}(2)-\mathrm{H}(2) \mathrm{N} \cdots \mathrm{O}(1)$ & $0.88(5)$ & $2.08(6)$ & $2.947(5)$ & $170(5)$ & $1+\mathrm{x}, \mathrm{y}, \mathrm{z}$ \\
\hline $\mathrm{C}(3)-\mathrm{H}(3 \mathrm{~A}) \cdots \mathrm{N}(4)$ & 0.98 & 2.59 & $3.478(6)$ & 151 & $1+\mathrm{x}, \mathrm{y}, \mathrm{z}$ \\
\hline $\mathrm{C}(9)-\mathrm{H}(9) \cdots \mathrm{N}(5)$ & 0.95 & 2.38 & $2.742(6)$ & 102 & -- \\
\hline $\mathrm{C}(14)-\mathrm{H}(14) \cdots \mathrm{O}(1)$ & 0.95 & 2.30 & $2.932(5)$ & 124 & -- \\
\hline
\end{tabular}

The molecular structure along with the crystallographic numbering scheme of PropPTMP-ths is given in Figure 2. The compound crystallizes in monoclinic crystal system with space group $\mathrm{P} 2{ }_{1} / \mathrm{c}$. Each unit consists of two asymmetric molecules of ligand along with two molecules of co-crystallized solvent DMSO molecule. The pyrazolone ring (N5-N4-C6-C5-C7) and phenyl (C9-C10-C11-C12-C14-C15) rings do not lie in the same plane and deviate with dihedral angle of $27.34^{\circ}$. The bond length of C6-O1 1.246(6) $\AA$ and $\mathrm{S}(1)-\mathrm{C}(1) 1.682(6) \AA$ is in good agreement with a carbon-oxygen and carbon-sulphur double bond respectively. The bond length between C9-C10 $=1.398(7) \AA$ is quite close to that obtained for aromatic ring system whereas, $\mathrm{N}(3)-\mathrm{C}(2) 1.346(7) \AA$ and $\mathrm{N}(5)-\mathrm{C}(7)$ 1.316(7) consists well with a carbon-nitrogen double bond. Pertinent bond lengths and angles for compound PTMPP-THSC are listed in Table 2 and are lying in the reported range.
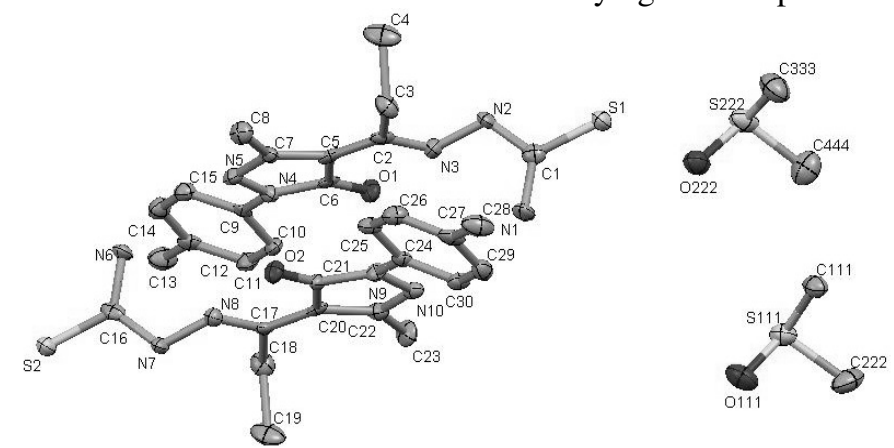

Figure 2. Molecular structure of compound PropPTMP-ths 
Weak force studies reveal that fourteen hydrogen bonds are formed in the molecular packing of this compound. Six hydrogen bonds are conventional hydrogen bonds whereas remaining eight bonds are non-conventional hydrogen bonds. The non-conventional hydrogen bonds involve $\mathrm{C}-\mathrm{H}$ unit as donor groups, whereas, acceptors are oxygen, nitrogen and sulphur atoms (Table 3).

Crystal packing of compound PropPTMP-ths involving six intermolecular hydrogen bonding is as shown in Figure 3 which consists of 18-membered pseudo cavity formed by hydrogen binding.

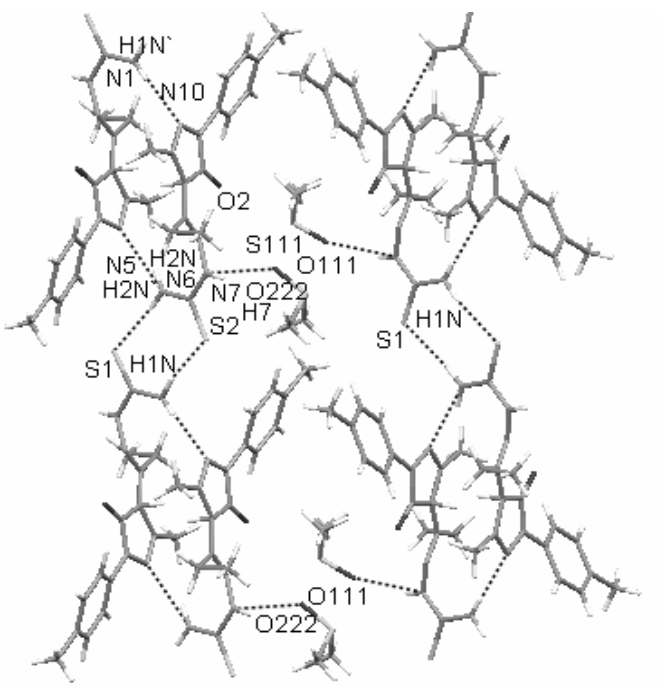

Figure 3. Packing of PropPTMP-ths forming cavity

The molecular structure along with the crystallographic numbering scheme of AcPTMP-ths is depicted in Figure 4. The compound crystallizes in monoclinic crystal system with space group $\mathrm{P} 2_{1} / \mathrm{n}$. Each unit consists of four molecules of the compouns. The molecule is almost coplanar and the central pyrazolone ring (N5-N4-C5-C4-C6) slightly deviate from phenyl ring with dihedral angle of $2.65^{\circ}$. Carbon-oxygen and carbon-sulphur double are found to be C5-O1 1.249(5) $\AA$ and S(1)-C(1) 1.672(5)A respectively which are in good agreement with the reported literature values. Carbon-nitrogen double bond $\mathrm{N}(3)-\mathrm{C}(2) 1.341(7) \AA$ and $\mathrm{N}(5)-\mathrm{C}(6)$ $1.305(5)$ consists well and the bond length between $\mathrm{C} 14-\mathrm{C} 13=1.382(6) \AA$ is quite close to that obtained for aromatic ring system. All other bond lengths and angles for compound AcPTMP-ths are listed in Table 2 and are lying in the reported range.

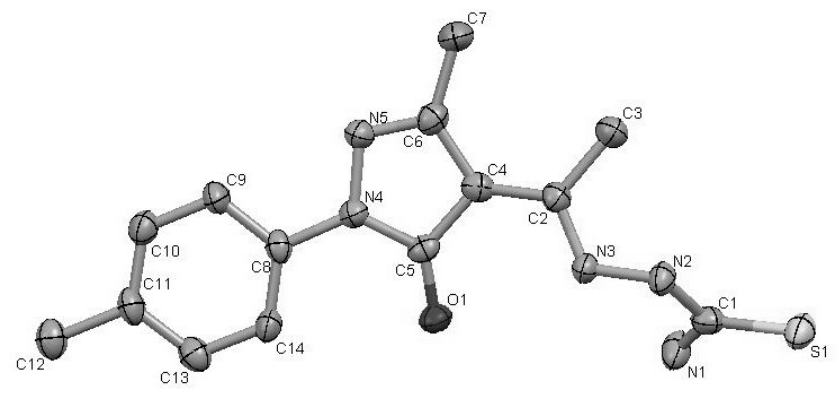

Figure 4. Molecular structure of compound AcPTMP-ths 
Weak force studies reveal the presence of seven hydrogen bonds in the molecular packing of this compound. Four hydrogen bonds are conventional hydrogen bonds whereas remaining three bonds are non-conventional hydrogen bonds. The non-conventional hydrogen bonds involve $\mathrm{C}-\mathrm{H}$ unit as donor groups, whereas, acceptors are oxygen, nitrogen and atoms (Table 3).

Chemical shift of hydrogen in the IR spectrum, the $v(\mathrm{~N}-\mathrm{H})$ spectral region is broad, showing the existence of N-H-O hydrogen bond. The band for $v(\mathrm{C}=\mathrm{O})$ at $1628 \mathrm{~cm}^{-1}$ is at lower wave number than that usually found for carbonyls, reflecting the involvement in hydrogen bonding with $\mathrm{NH}$ of the thiosemicarbazone and pyrazol-5-one compound. In ${ }^{1} \mathrm{H}$ NMR N(1) is easily distinguished from that of $\mathrm{N}(2)$ because the latter (7.161 ppm) appears as a doublet due to that the two hydrogen atom on $\mathrm{N}(2)$ are nonequivalent because one of them is involved in hydrogen bonding, which is consistent with the crystal structure analysis. The single peak at $8.3 \mathrm{ppm}$ is assignable to the $\mathrm{N}(1)-\mathrm{H}$. The single of $10.2 \mathrm{ppm}$ is not a unit because $\mathrm{N}(5)$ share the same hydrogen with $\mathrm{O}$ on the neighboring molecule.

The x-ray structural investigation of AcPTMP-ths shows that in this compound has a stair form packing arrangement. An ORTEP plot along with the atom numbering scheme of AcPTMP-ths is given in Figure 4 and 5. The figure also describes arrangement of the molecules in the unit cell with intermolecular content through atoms with other atoms of AcPTMP-ths. The bond lengths and angles for compound AcPTMP-ths are listed in Table 2.

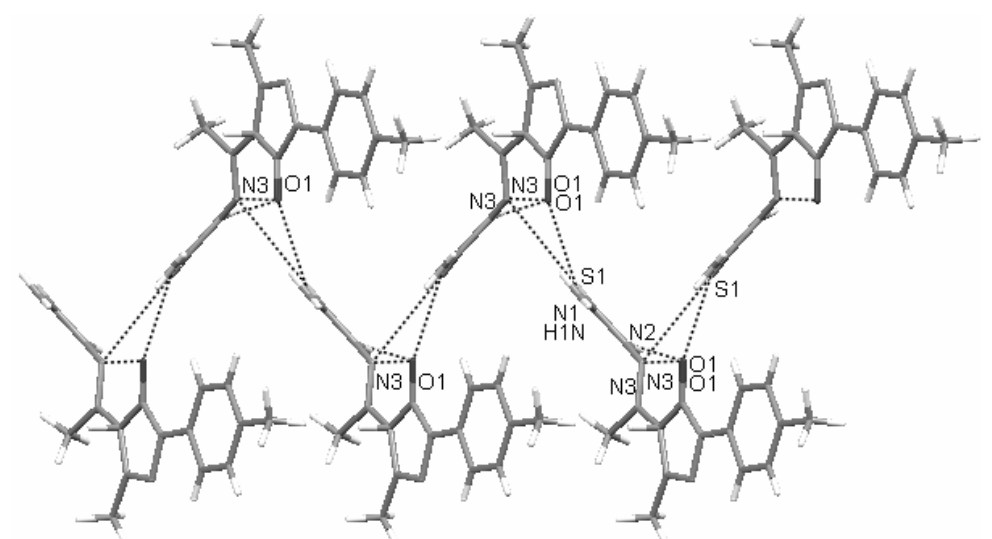

Figure 5. Packing of AcPTMP-ths showing parallel chains linked through hydrogen bonding

\section{Synthesis of Novel 4-acylthiosemicarbazon-2-pyrazoline-5-one}

The reaction of 3-methyl-1-(4-methylphenyl)-2-pyrazoline-5-one (PTMP) with acetyl chloride or propionyl chloride were carried out under the ordinary condition. The reaction 4-acyl-2-pyrazoline-5-one with thiosemicarbazide produce Schiff base as carried out in alcohol such as ethanol or methanol at reflux temperature and crystallization by aqueous alcohol for purification. A yellow prismatic crystal of the titled compounds obtained. The formation of 4-acylthiosemicarbazon-2-pyrazoline-5-one was confirmed by spectral data viz. ${ }^{1} \mathrm{H}$ NMR, ${ }^{13} \mathrm{C}$ NMR and FTIR.

\section{Antibacterial activity investigation}

In the present study, the antibacterial activities of the AcPTMP-ths, PropPTMP-ths and standard drugs were tested by the agar-cup method in DMF solvent (at concentration of $5000 \mu \mathrm{g} / \mathrm{mL}$ as well as $2500 \mu \mathrm{g} / \mathrm{mL}$ ) and were checked against Gram negative bacteria Escherichia coli MTCC-739), Pseudomonas aeruginosa (MTCC-741), Salmonella typhi (MTCC- 
733), Proteus vulgaris (MTCC-1771) and Klebsiella pneumoniae (MTCC-109) and Gram positive bacteria Staphylococcus aureus (MTCC-96) and Bacillus subtilis (MTCC-619). Table 3 shows that AcPTMP-ths and PropPTMP-ths compounds have good antibacterial activities against these bacteria. The results (Table 4) showed that almost all compounds showed nearly better activity. It is interesting to note that due to the presence of pyrazolone group, these compounds were found to be efficient antibacterial agents. Use of these ligands system now covers a full of areas ranging from general consideration of metal-sulphur bonding and electron delocalization in transition metal complexes to potential biological activity work is under analysis.

Table 3. Antibacterial activities of AcPTMP-ths and PropPTMP-ths with drugs.

\begin{tabular}{|c|c|c|c|c|c|c|c|}
\hline \multirow{3}{*}{ Compounds } & \multicolumn{7}{|c|}{ Antibacterial activity (Zone size in $\mathrm{mm}$ ) } \\
\hline & \multicolumn{5}{|c|}{ Gram negative } & \multicolumn{2}{|c|}{ Gram positive } \\
\hline & $E c$ & $P a$ & $S t$ & $K p$ & $P v$ & $B s$ & $S a$ \\
\hline \multirow[t]{3}{*}{ AcPTMP-ths } & $\mathrm{A} 1=18$ & $\mathrm{~A} 1=17$ & $\mathrm{~A} 1=14$ & $\mathrm{~A} 1=19$ & $\mathrm{~A} 1=12$ & $\mathrm{~A} 1=20$ & $\mathrm{~A} 1=26$ \\
\hline & $\mathrm{A} 2=14$ & $\mathrm{~A} 2=15$ & $\mathrm{~A} 2=12$ & $\mathrm{~A} 2=16$ & $\mathrm{~A} 2=09$ & $\mathrm{~A} 2=23$ & $\mathrm{~A} 2=22$ \\
\hline & $\mathrm{A} 3=08$ & $\mathrm{~A} 3=08$ & $\mathrm{~A} 3=08$ & $\mathrm{~A} 3=08$ & $\mathrm{~A} 3=08$ & $\mathrm{~A} 3=08$ & $\mathrm{~A} 3=08$ \\
\hline \multirow{3}{*}{ PropPTMP-ths } & $\mathrm{B} 1=18$ & $\mathrm{~B} 1=17$ & $\mathrm{~B} 1=17$ & $\mathrm{~B} 1=17$ & $\mathrm{~B} 1=12$ & $\mathrm{~B} 1=13$ & $\mathrm{~B} 1=27$ \\
\hline & $\mathrm{B} 2=13$ & $\mathrm{~B} 2=13$ & $\mathrm{~B} 2=10$ & $\mathrm{~B} 2=13$ & $\mathrm{~B} 2=09$ & $\mathrm{~B} 2=10$ & $\mathrm{~B} 2=21$ \\
\hline & $\mathrm{B} 3=08$ & $\mathrm{~B} 3=08$ & B3 $=08$ & $\mathrm{~B} 3=08$ & B3 $=08$ & $\mathrm{~B} 3=08$ & $\mathrm{~B} 3=08$ \\
\hline Ampicillin (20mcg) & 17 & 11 & 16 & 14 & 18 & 08 & 09 \\
\hline Cefotaxim(30mcg) & 23 & 13 & 15 & 11 & 18 & 18 & 14 \\
\hline Gentamicin(10mcg) & 18 & 11 & 17 & 23 & 13 & 17 & 19 \\
\hline Levofloxacin $(5 \mathrm{mcg})$ & 20 & 28 & 18 & 06 & 14 & 18 & 19 \\
\hline Gatifloxacin (10mcg) & 14 & 25 & 17 & 10 & 19 & 20 & 21 \\
\hline Amikacin (30mcg) & 18 & 21 & 22 & 20 & 20 & 18 & 19 \\
\hline $\begin{array}{l}\text { Chloramphenicol } \\
\text { (30mcg) }\end{array}$ & 20 & 16 & 16 & 18 & 17 & 16 & 20 \\
\hline Ofloxacin $(5 \mathrm{mcg})$ & 08 & 24 & 22 & 17 & 16 & 19 & 20 \\
\hline \multicolumn{8}{|c|}{$\begin{array}{l}\text { Ec-Escherichia coli (MTCC-739), Pa-Pseudomonas aeruginosa (MTCC-741), St- } \\
\text { Salmonella typhi (MTCC-733), Pv-Proteus vulgaris (MTCC-1771), Kp-Klebsiella } \\
\text { pneumoniae (MTCC-109), Sa-Staphylococcus aureus (MTCC-96) and Bs-Bacillus subtilis } \\
\text { (MTCC-619). } \\
\text { A1, B1, - 5000 } \mu \mathrm{g} / \mathrm{mL} \text { concentration of respective compound } \\
\text { A2, B2, - } 2500 \mu \mathrm{g} / \mathrm{mL} \text { concentration of respective compound } \\
\text { A3, B3, - As solvent (DMF) control }\end{array}$} \\
\hline
\end{tabular}

Discussion here is restricted only to $\mathrm{O}, \mathrm{S}$ and $\mathrm{N}$ Containing ligands, especially thiosemicarbazide and its amine substitution like 4-methyl thiosemicarbazide, 4-phenyl thiosemicarbazide, 4,4-dimethyl thiosemicarbazide and 4,4-diphenyl thiosemicarbazide.

\section{Method}

The antibacterial activities of AcPTMP-ths and PropPTMP-ths were studied by standard cupplate-agar diffusion method using Mueller-Hinton agar (Himedia, Bombay) ${ }^{25}$. The measured quantity of the fresh culture of the respective test organism $(0.5 \mathrm{~mL})$ was added to each heated (nearly $<40{ }^{\circ} \mathrm{C}$ ) agar media tubes. The tubes were shaken well and the inoculated media were poured in the sterilized petri dishes $(10 \mathrm{~cm}$ diameter $)$ and then allowed to set for $30 \mathrm{~min}$. The test solutions of $5000 \mu \mathrm{g} / \mathrm{mL}$ and $2500 \mu \mathrm{g} / \mathrm{mL}$ dilutions of the respective AcPTMP-ths and PropPTMP-ths $(5000 \mu \mathrm{g} / \mathrm{mL}$ and $2500 \mu \mathrm{g} / \mathrm{mL})$ were prepared in Dimethyl- 
formamide (DMF) .The concentrations of tested compounds were decided by MIC (Minimal Inhibitory concentration) method and selection of test cultures was decided by performing ditch method. Four cups of $5 \mathrm{~mm}$ diameter were cut in the culture media on the petridishes. A 50 micro liter $(\mu \mathrm{L})$ solution of particular diluted compound $(5000 \mu \mathrm{g} / \mathrm{mL}$ or $2500 \mu \mathrm{g} / \mathrm{mL})$ was filled with micropipette in the four cups of one of the Petri dishes. All the petri dishes were allowed to remain in the refrigerator maintained at $<10{ }^{\circ} \mathrm{C}$ for $<1 \mathrm{~h}$ to allow diffusion of the respective solutions. The petridishes were then transferred to an incubator maintained at $<37{ }^{\circ} \mathrm{C}$ and kept for nearly $24 \mathrm{~h}$. The zones of inhibition appeared were measured with vernier calipers. The control of DMF showed slight activity. The activities of all compounds are represented by size of the diameter of zone of inhibition in millimeter.

The antibacterial activity of standard antibiotics was performed by following standard Kirby-Bayer method (combi-disc method, purchased from Pathoteq Biological Laboratories (India)). The antibacterial activity of all known antibiotics is represented by size of the diameter of zone of inhibition in millimeter.

\section{Conclusion}

A number of multi-functionalized 4-acylthiosemicarbazone-2-pyrazoline-5-ones were conveniently prepared by literature method. Investigation of biological activities of this type of ligands and their metal complexes have identified them as promising potential antibacterial agent against Gram-positive as well as Gram-negative bacteria. They have broad-spectrum activity and were found as competitive as marketed known antibiotics drugs.

\section{Acknowledgment}

We are grateful to Dahod Anaj Mahajam Sarvajanic Education Society and Principal, Navajivan Science College, Dahod for the Laboratory facilities, Prof. Hasmukh Modi Department of Life science, Gujarat University for analysis (biological acivity), Pradeep Mathur for single crystal x-Ray Powder diffraction analysis done at IIT, powai Mumbai and Kamlesh Modi (Prima Chemicals) for providing free pyrazolone-5-one intermediate.

\section{References}

1. Kizilcikli I, Ulkuseven B, Dasdemir Y and Akkurt B, Synth React Inorg Met-Org Chem., 2004, 34(4), 653-665.

2. Casas J S, Garcia-Tasende M S and Sordo J, Coord Chem Rev., 2000, 209(1), 197-261.

3. Mishra D, Naskar S, Drew M G B and Chattopadhyay S K, Inorg Chim Acta, 2006, 359(2), 585-592.

4. Novakovic S B, Bogdanovic G A and Leovac V M, Polyhedron, 2006, 25(5), 1096.

5. $\quad$ Singh N K and A. Srivastava A, Trans Met Chem., 2000, 25(2), 133-140.

6. Mehrotra R C, Bohra R and Gaur D P, Metal $\beta$-Diketonates and allied Derivatives, Academic Press, New York, 1978, 76-109.

7. $\quad$ Yang L, Jin W and Lin J, Polyhedron, 2000, 19, 93.

8. Peng B, Liu G, Liu L, Jia D and Yu K, J Mol Srtuct., 2004, 692, 217-222.

9. Marchetti F, Pettinari C, Cingolani A, Pettinari R, Rossi M and Caruso F, $J$ Organomet Chem, 2002, 645, 134.

10. Santos I G, Abram U, Alberto R, Lopez E V and Sanchez A, Inorg Chem., 2004, 43, 1834-1836.

11. Liu Guang-fei, Liu lang, Hu Xin, Jia Dian-Ze and Yu Kai-Bei, Chin J Srtuct Chem., 2006, 25(10), 1233-1237.

12. Jain S K, Garg B S and Bhoon Y K, Trans Met Chem., 1986, 11, 89. 
13. Rana A K, Nayan Parekh R, Harish Dabhi R and Sunil Nadkarni S, E-J Chem., 2009, 6(3), 747-752.

14. Guo D S, Huang R O and Gao R H Z G, J Chin Univ., 1996, 17(2), 255.

15. Rana A K and Shah J R, J Indian Chem Soc., 1981, 58, 1100.

16. Rana A K and Shah J R, Indian J Chem., 1982, 21, 177.

17. Kharodawala M J and Rana A K, Synth React Inorg Met Org Chem., 2003, 33(8), 1483-1504.

18. Rana A K, Dabhi H R and Pancholi A M, Orient J Chem., 1996, 12, 287.

19. Rana A K and Kharodawala M J Asian J Chem., 2002, 14(2), 703-708.

20. Rana A K, Bhoi D K and Dabhi H R, Asian J Chem., 2009, 21(2).

21. Jensen B S, Acta Chem Scand., 1959, 13, 1668-1670.

22. Tang X C, Jia D Z, Liang K, Zhang X and Zhou Z Y, J Photochem Photobiol A Chem., 2000, 134, 23.

23. Liu L and Jia D Z, J Photochem Photobiol A Chem., 2002, 153.

24 Spek A L, J Appl Cryst., 2003, 36, 7-13.

25. Barry A L, The Antimicrobic Susceptibility Test Principle and Practice, 1976, 180. 


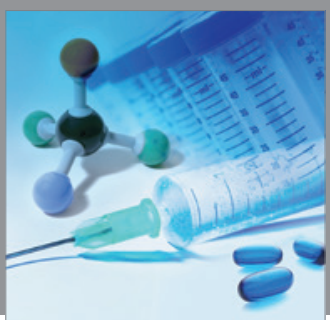

International Journal of

Medicinal Chemistry

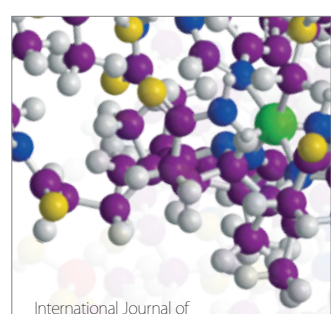

Carbohydrate Chemistry

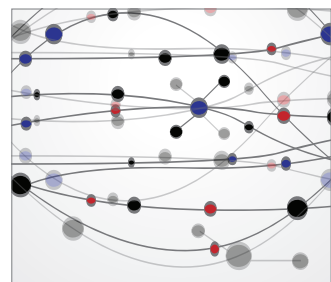

The Scientific World Journal
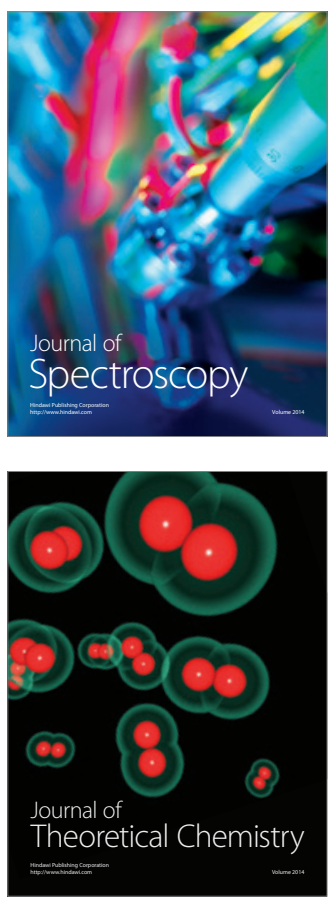
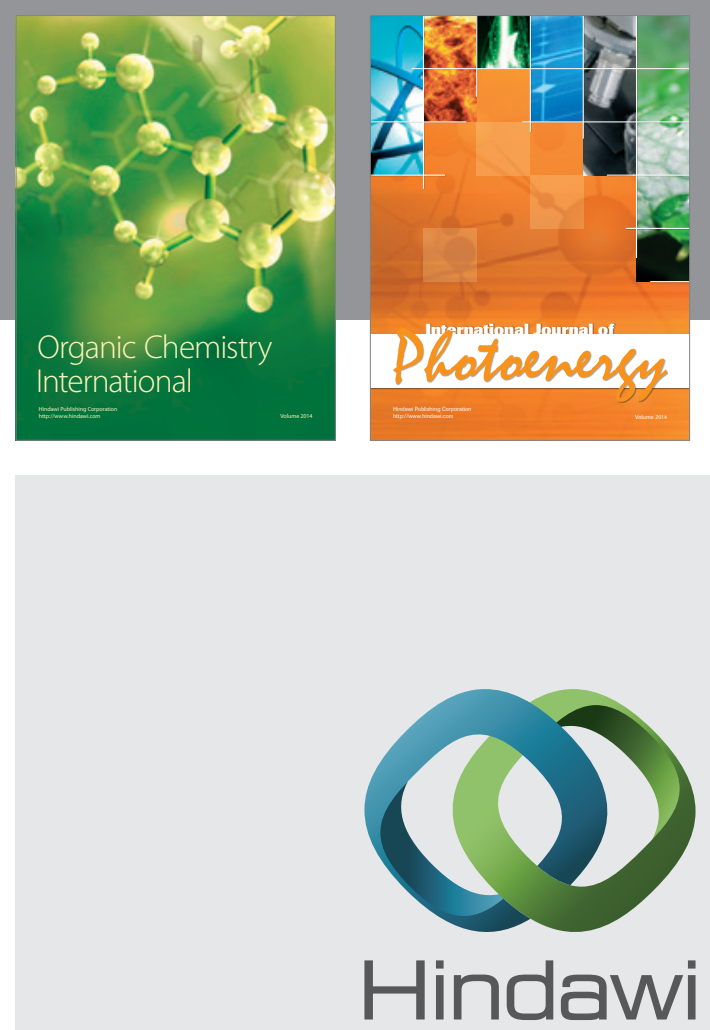

Submit your manuscripts at

http://www.hindawi.com
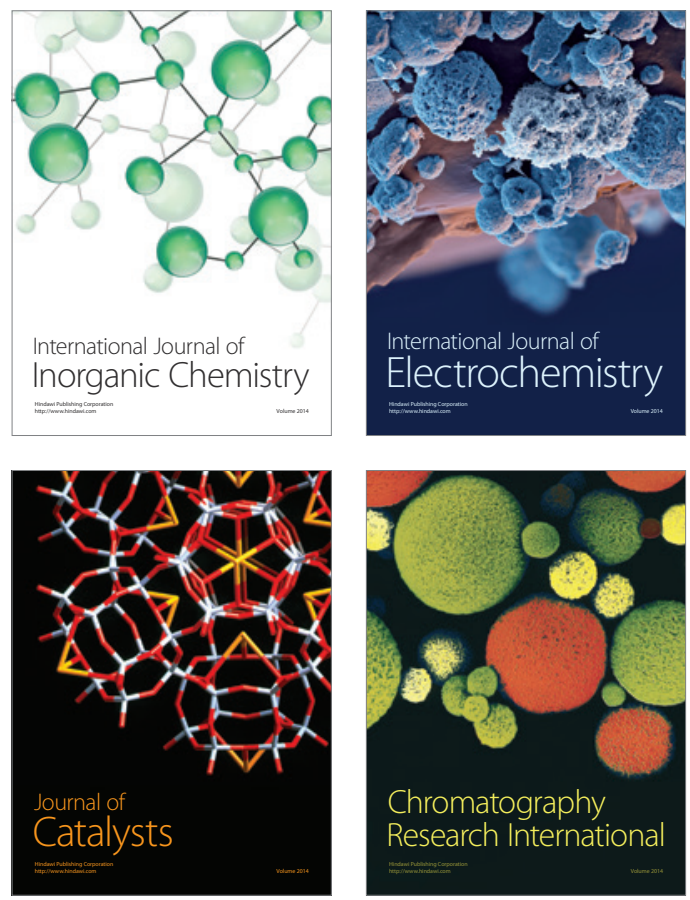
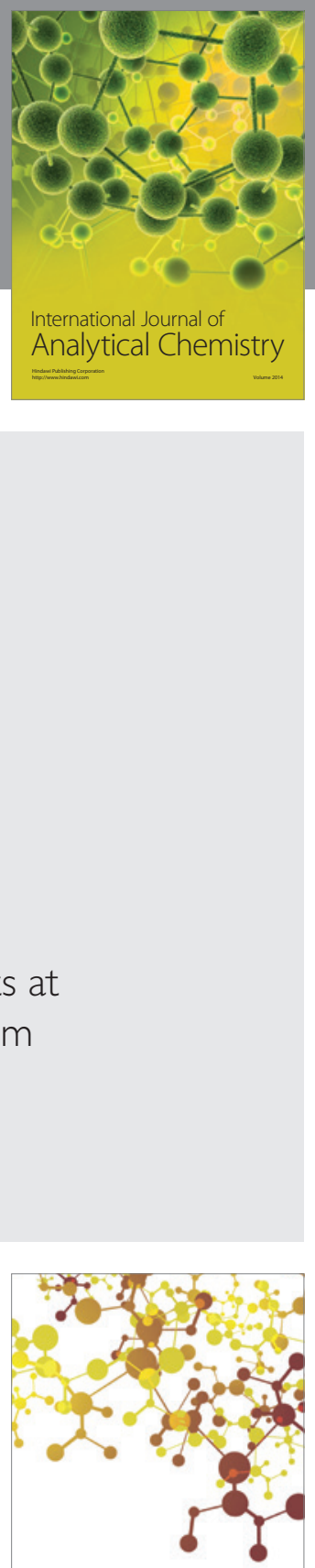

Journal of

Applied Chemistry
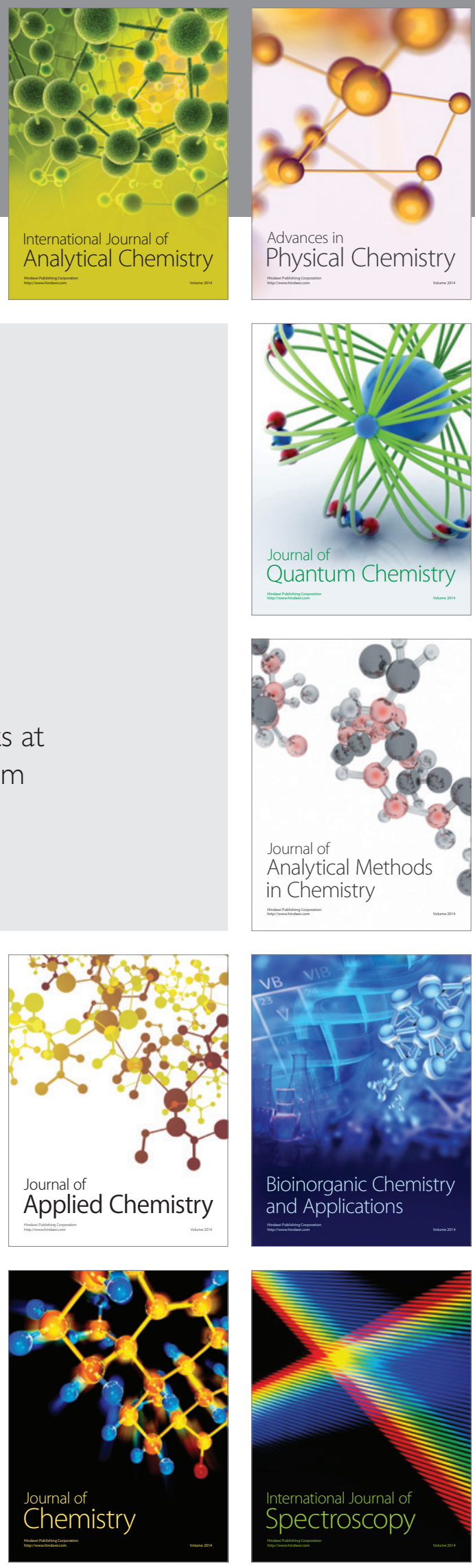